\title{
A new type of shell malformation caused by epizoans in Late Jurassic ammonites from Central Russia
}

\author{
Aleksandr A. Mironenko \\ Acta Palaeontologica Polonica 61 (3), 2016: 645-660 doi:http://dx.doi.org/10.4202/app.00100.2014
}

A new type of shell damage on Late Jurassic ammonite Kachpurites fulgens is described. The new type of shell malformation consists of small elongated pits, arranged in groups on the surface of ammonite shell and concentrated near the terminal aperture. The examination of the pits demonstrated no signs of drilling, biting, or healing of punctures. The shell layers in the pits are bent downward without changing in thickness. At the same time the pits, in some cases, significantly distort the shape of the shell walls. Deformed growth lines are associated with some of the pits. All of this supports the hypothesis that the pits had been formed by epifauna located at a flexible uncalcified part of the periostracum in the apertural region of the growing ammonite shell. It is likely that epizoan attachment led to the deformation of the thin periostracum film and to the distortion of the growing shell wall. The nature of epizoans is discussed, but remains unclear due to their rather poor preservation. The relationship between epizoans and ammonites is also an open question: they could have been parasites, but other types of biotic relationships cannot be entirely ruled out.

Key words: Ammonoidea, parasites, Craspeditidae, Kachpurites, epifauna, Jurassic, Russia.

Aleksandr A. Mironenko [paleometro@gmail.com], Geological Institute of RAS, Pyzhevski lane 7, 119017 Moscow, Russia.

This is an open-access article distributed under the terms of the Creative Commons Attribution License (for details please see creativecommons.org), which permits unrestricted use, distribution, and reproduction in any medium, provided the original author and source are credited. 
